UDC 81'23: [811.111 + 811.161.2]:81'25

DOI https://doi.org/10.32841/2409-1154.2021.47-3.32

\author{
Okulova L. O., \\ Associate Professor at the Department of Philology \\ Odesa National Maritime University
}

\title{
THE PECULIARITIES OF RENDERING PERSUASION STRATEGY IN TRANSLATING AMERICAN BEAUTY-INDUSTRY COMMERCIALS INTO UKRAINIAN
}

Summary. The article is dedicated to the problem of the interdisciplinary character which is also urgent for psycholinguistics and translation studies. In the focus of the analysis there are linguistic means of representing persuasion strategy in American beauty-industry commercials and the key translation strategies, tactics and devices. Persuasion is interpreted as mental influence upon co-communicant's or target audience's decisions aimed at encouraging certain actions or in other words manipulation. It has been discovered that persuasion strategy is made manifest in speech through such speech impact techniques as stylistic devices, compositional structure of a speech product, cognitive and logical operations. On the stylistic level there have been distinguished such means as rhetoric questions, parallel constructions, lexical repetitions, inversion, hyperbole, litotes, meiosis. Among the pragmatic means there have been outlined the forms of address, speech actions explanation, indirect speech acts and speech acts of the mixed type.

It has been concluded that the dominant ones are the strategy of re-addressing and of tertiary translation, while the most widely occurred tactics are the tactic of rendering relevant information, the tactic correct presentation and the tactic of linguistic and cultural adaptation. The analysis of the translation devices has revealed the predominance of such simple devices as transplantation, transcoding, different types of replacements (contextual replacement, concretization, functional replacement). On the level of complex translation transformations there has been resumed that the most widely used are descriptive translation, antonymous translation and the technique of semantic development. The research is perspective and its findings may be employed as a means of translation optimization in the field of beauty industry.

Key words: psycholinguistics, persuasion strategy, beauty industry, translation strategies, tactics, devices.

Introduction. The ability to persuade is a powerful means of manipulating the personality, its likings, intentions and actions. Persuasion may be realized only by means of speech influence techniques and the corresponding linguistic devices of their actualization in a communicative situation. Argumentation has been thoroughly researched by such well-known scholars as B.M. Baranov [1], I.M. Horelov [2], V.V. Dementyev [3;4], V.P. Zernetskyi [5], K.F. Sedov [6], I.A. Sternin [7], Ch.U. Larson [8]. However, all the recent researches have been so far focused upon the problems of persuasion strategy rendering issue mostly in mass media and political discourse.

The subject of the research is persuasion strategy in American beauty-industry commercials, the object - linguistic means of the strategy actualization and their rendering in Ukrainian translation. The urgency of this research is conditioned by the shortage of publications on persuasion strategy realization means rendering in translational aspect.

The objective and tasks. The objective of the research is to define peculiarities of representing persuasion strategy on different levels of the English language in American beautyindustry commercials in their aspect of the ways of their rendering in translation. To fulfill the given task the following must be done: to study theoretical sources on the chosen topicality; to define the notions "persuasion", "persuasion strategy", "beautyindustry"; to analyze linguistic means of realizing the strategy under investigation in American commercials on different language levels; to research strategies, tactics and operations of rendering the analyzed means in Ukrainian translation.

Research materials and methods. In accordance with the subject, object, objective and tasks the following research methods have been employed: method of theoretical generalization to describe the findings; comparative method to contrast source texts and translation texts, method of analysis to give an outline of the linguistic material under investigation. The research has been carried out on the basis of American beauty-industry commercials advertising the products produced by DMK USA.

Results and discussion. The whole scope of the research material has been selected to illustrate peculiarities of the persuasion strategy employment in the field of beauty-industry. The sampling has been constituted by DMK commercials, advertising leaflets and texts on the website www.dmk.us and its Ukrainian version www.dmk.ua.

Argumentation is being studied as a communicative strategy which allows to affect a co-communicant through thorough selection of information and communicative techniques. Communicative strategy is interpreted as creative realization of the plan of speech product formation aimed at achieving the same communicative task. The key parameters of argumentation are intentionality, illocution and conventionality.

Among the peculiarities of persuasion strategy there are thenecessity to plan speech actions for the initiation of argumentation, analysis of possible co-communicant's responses, brevity and logics of speech behavior, the strategy's reliance upon communicants' common background knowledge aimed at combining personal and collective picture of the world, wide employment of verbal and non-verbal communicative means. Persuasion strategy is made manifest in speech through such speech impact techniques as stylistic devices, compositional structure of a speech product, cognitive and logical operations.

Persuasion is interpreted as mental influence upon co-communicant's or target audience's decisions aimed 
at encouraging certain actions or in other words manipulation. However, persuasion arguments may be addressed to different aspects of personality besides the mental sphere - sensations, will, emotions, consciousness and even subconscious.

During the experiment two prominent persuasion strategies have been outlined which are most recurrent in beauty-industry commercials. Beauty-industry is defined as life sphere connected with appearance, in particular the sphere of beauty service, cosmetics purchases, show-business and film industry spheres.

Persuasion strategy has been researched as warning of the possible negative consequences in case of not purchasing cosmetics advertised and strategy of discredit of competitors in the field of beauty industry.

To represent persuasion the speaker employs linguistic means of different levels: lexical means with denotative meaning of softening to reduce the categorical meaning of the utterance (only, just, merely, please), intensifiers (very, quite, rather), pragmatic operators (but, or, so, because, you know, I (don't) think, 1 mean, after all, of course, listen, look), emotionally colored and evaluative lexis. According to the research findings this rank of representatives is constituted by $45 \%$ of the general sampling.

Less numerous are grammatical means represented by modal verbs (can, may, might, could, should), Conditional Mood and Subjunctive Mood forms, questions-negations and questionsrequests expressing the speaker's opinion and encouraging the audience for the dialogue ("why don't ...?", "would you mind ...?", "Don't you agree...?"),parenthetical words and phrases, indicators of hesitation pauses, interrogations ("well, well..", "let's see...", "for God's sake ...", "it would seem that..."),emphatic constructions, complex sentences with adverbial clauses. This level has constituted about $25 \%$ of the general sampling.

On the stylistic level in the focus of the research there are rhetoric questions, parallel constructions, lexical repetitions, inversion, hyperbole, litotes, meiosis. Among the pragmatic means there should be outlined the forms of address, speech actions explanation,

indirect speech acts and speech acts of the mixed type (for example, advise, accusation, apology, sympathy). The percentage of the stylistic devices is $30 \%$ of the sampling, as for the pragmatic devices they are combined with lexical, grammatical and stylistic so it may be stated that their general amount in comparison with neutral utterances makes up about $60 \%$ of the whole sampling.

All the texts under analysis have been classified as commercials with the main function of manipulation: audience attraction, its motivation for purchasing certain cosmetics, promotion of definite brands, marketing. In the textual part of the commercial on the website DMK there are many references to film industry, Hollywood, as a symbol of success.

Persuasion strategy is realized in the texts under analysis via complex employment of linguistic means on different levels. The most recurrent means are lexical stylistic devices, in particular epithets, metaphors and metonymies. In the given example the following metaphors have been employed ("revolution", "has gone a step further", "key to the results", "build a world of confidence", "rebuild lives"), метонімію ("the hands of professionals") та епітет ("valuable", "youthful").

The analysis of the American beauty industry commercials advertising DMK Cosmetics production and their authorized Ukrainian translations on the official site $D M K$ in Ukraine www. dmk.ua has resulted in the following conclusions as to the frequency of persuasion strategy realization means employment.

Firstly, it has been discovered that lexical means are more widely spread compared with syntactic means. Secondly, it has been drawn a conclusion that more frequent are means based upon transfer of meaning.

According to the grounding of the transfer there have been differentiated metaphors and metonymies, according to the part of speech metaphors realized in verbs and nouns have been differentiated from epithets realized in adjectives and adverbs respectively. The regularity has been illustrated by the figure given below.

Table 1

Illustrative examples of the texts under analysis

\begin{tabular}{|c|c|}
\hline The source text & The Ukrainian translation \\
\hline $\begin{array}{c}\text { INTRODUCING DMK COSMETICS } \\
\text { A revolution in corrective make-up. After decades of constant innovation and } \\
\text { critical acclaim, DMK has gone a step further and extended its unique, holistic } \\
\text { skin concept into makeup. Our long-standing reputation for excellence in skin } \\
\text { revision now comes full circle. Whether you are an individual with unique skin } \\
\text { conditions, a post-operative client, an industry professional or simply someone } \\
\text { looking for superior makeup, DMK Cosmetics has you covered. Quality without } \\
\text { compromise. }\end{array}$ & 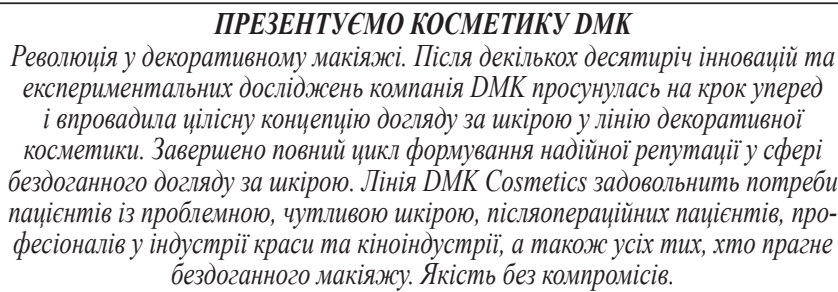 \\
\hline $\begin{array}{c}\text { FILM STUDIOS \& PRO PANEL } \\
\text { The only way to truly test any cosmetic is to place it in the hands of profes- } \\
\text { sionals. DMK Cosmetics are fortunate to have a world-class group of industry } \\
\text { professional makeup artists who test, evaluate and teach make-up. The Pro } \\
\text { Panel has been valuable in performing tests and evaluations on all DMK } \\
\text { Cosmetic products to assure the quality and superior formulation of all products } \\
\text { we manufacture. }\end{array}$ & 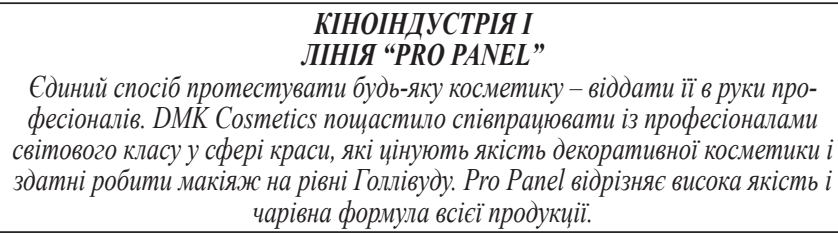 \\
\hline $\begin{array}{c}\text { DMK is the World Leader in Paramedical Skin Revision }{ }^{T M} \text { Education. DMK } \\
\text { believes that the origin of most skin conditions is a result of disharmony within } \\
\text { the skin. }\end{array}$ & $\begin{array}{l}\text { Компанія DMK є світовим лідером з навчання лікування шкіри продукиією } \\
\text { лінії Paramedical Skin Revision }{ }^{T M} \text {. На думку DMK, причина більшості проблем } \\
\text { зі шкірою - у порушенні балансу. }\end{array}$ \\
\hline $\begin{array}{c}\text { Using the principles of biochemistry, DMK has formulated a range of treatments } \\
\text { and products that encourage skin to perform like youthful healthy skin. DMK } \\
\text { is building a World of Confidence }{ }^{\circledR} \text { through its unique DMK Skin Revision } \\
\text { concept and treatments. DMK's educational program for its estheticians and } \\
\text { medical professionals is key to the exceptional results that rebuild skin and } \\
\text { rebuild lives from the outside - in. }\end{array}$ & $\begin{array}{c}\text { На основі принципів біохімії компанія DMK розробила протоколи лікування } \\
\text { та косметологічну продукцію, які перетворюють шкіру на молоду і здорову. } \\
\text { DMK створює світ впевненості через унікальну концепцію лінії DMK Skin } \\
\text { Revision }^{\text {TM }} \text {. Освітні програми DMK для косметологів і лікарів є ключем до } \\
\text { виняткових результатів - оновлення шкіри та життя. }\end{array}$ \\
\hline
\end{tabular}




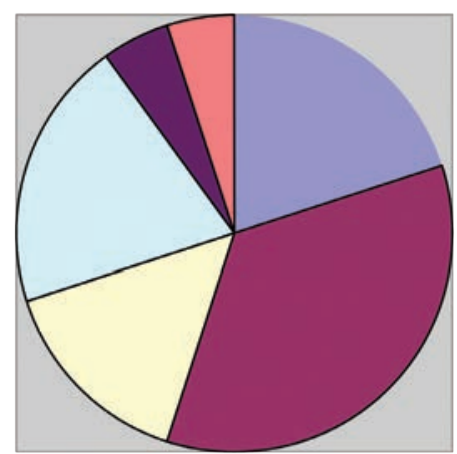

$\square$ capitalization

$\square$ metaphor

ametonymy

$\square$ epithet

aellipsis

口inversion

Fig. 1. The correlation of various means of realizing persuasion strategy, $\%$

The combined table of the findings

of the American beauty industry commercials persuasion strategy realization means analysis, $\%$

\begin{tabular}{|c|c|c|}
\hline $\begin{array}{c}\text { The realization } \\
\text { means }\end{array}$ & $\begin{array}{c}\text { Percentage, } \\
\text { B \% }\end{array}$ & Example \\
\hline capitalization & 20 & $\begin{array}{c}\text { World Leader; } \\
\text { World of Confidence; } \\
\text { Skin Revision }\end{array}$ \\
\hline metaphor & 35 & $\begin{array}{c}\text { rebuild lives; key to the results; DMK } \\
\text { believes; encourage }\end{array}$ \\
\hline metonymy & 15 & place in the hands of the professionals \\
\hline epithet & 20 & youthful skin \\
\hline ellipsis & 5 & Quality without compromise \\
\hline inversion & 5 & $\begin{array}{c}\text { DMK's educational program for its } \\
\text { estheticians and medical professionals } \\
\text { is key... }\end{array}$ \\
\hline
\end{tabular}

On the next stage of the research Ukrainian translations from the beauty industry commercial site www.dmk.ua have been investigated. The objective was to define the dominant strategies, tactics and operations of rendering persuasion strategy realization means in Ukrainian translation.

It has been stated that both the strategy of tertiary translation has been combined with re-addressing strategy. Tertiary translation strategy is motivated by the influence of the interested parties in the process of translation, in particular marketing policy of the company DMK which initiated and sponsored translation.

Re-addressing strategy has been preconditioned by distinctive discrepancies in such characteristics of the target audience as different cultural background, different stereotypes of behavior and appearance, the degree of awareness of the material and general preparedness in the field of cosmetology, social differences etc. Among the translation tactics the most frequent are the tactic of correct information presentation, the tactic of relevant information rendering and the tactic of linguistic and cultural adaptation. The correlation of these tactics is given in Figure 2.

As for the translation operations the most frequent have proved to be translation transformations of transplantation (to convey names of companies and brand names), loan translation, transcoding (to present beauty products), contextual replacement, concretization, functional replacement, descriptive translation (explication), antonymous translation and semantic development. The data are presented in the Tables 3.

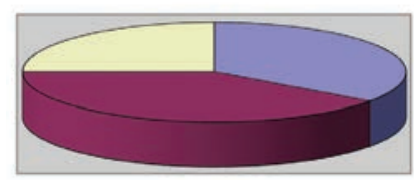

\begin{tabular}{|l|}
\hline$\square$ tactic of correct \\
information \\
presentation \\
$\square$ tactic of relevant \\
information \\
rendering \\
$\square$ tactic of linguistic \\
and cultural \\
adaptation \\
\hline
\end{tabular}

Fig. 2. The correlation of translation tactics for rendering persuasion strategy Ukrainian translation, \%

Table 3

The combined table of the findings of the simple translation operations analysis for rendering persuasion strategy in Ukrainian translation

\begin{tabular}{|c|c|c|}
\hline $\begin{array}{c}\text { Simple } \\
\text { translation } \\
\text { operations }\end{array}$ & $\begin{array}{l}\text { Frequency of } \\
\text { employment, } \\
\text { in } \%\end{array}$ & Examples \\
\hline transplantation & 15 & Paramedical Skin Revision ${ }^{T M}, D M K$ \\
\hline transcoding & 10 & Дi-Eм-Кей, “аспе”- «акне» \\
\hline loan translation & 15 & $\begin{array}{c}\text { "educational program" - «освітня } \\
\text { програма»" }\end{array}$ \\
\hline $\begin{array}{c}\text { contextual } \\
\text { replacement }\end{array}$ & 20 & “origin"— «причина» \\
\hline concretization & 25 & "estheticians" - «косметологи» \\
\hline $\begin{array}{l}\text { functional } \\
\text { replacement }\end{array}$ & 15 & "rebuild skin" - «оновлення шкіри» \\
\hline
\end{tabular}

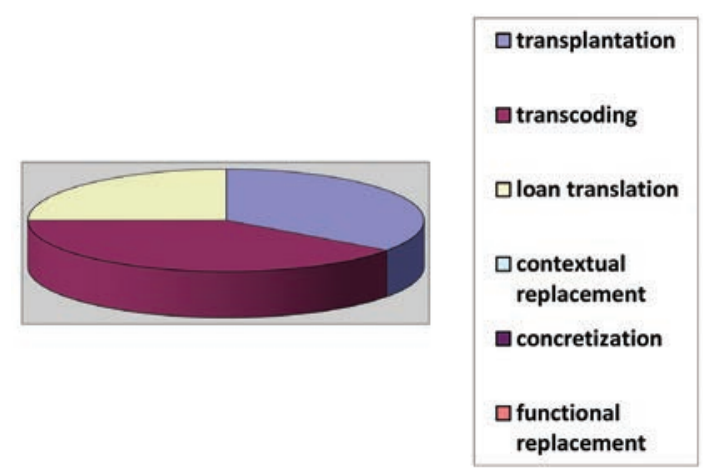

Fig. 3. The correlation of simple translation operations for rendering persuasion strategy in Ukrainian translation, \%
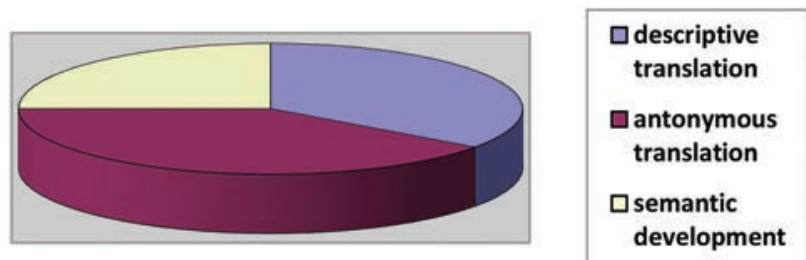

Fig. 4. The correlation of complex translation operations for rendering persuasion strategy in Ukrainian translation, \%

Conclusions. According to the results of the analysis of American beauty industry commercials aimed at defining dominant strategies, tactics and operations of rendering in Ukrainian translation linguistic means of persuasion strategy realization the two prominent translation strategies are the strategies of readdressing and tertiary translation. As for the translation tactics, the most recurrent gave proved to be the tactic of relevant information rendering, the tactic of correct information presentation and the tactic of linguistic and cultural adaptation. 
As far as the translation operations are concerned, the most frequent ones have proved to be transplantation, transcoding and replacements (contextual replacement, functional replacement, concretization). Among the complex translation operations there should be outlined antonymous translation, descriptive translation or explication and semantic development.

Perspective. The research is a promising study due to the possibility of extending the topicality by also adducing to the research extralinguistic means of persuasion strategy realization in American beauty industry commercials and their authorized Ukrainian translations.

\section{References:}

1. Баранов А.Н. Лингвистическая теория аргументации (когнитивный подход). Москва, 1990. 150 с.

2. Горелов І.М., Седов К.Ф. Основы психолингвистики. Москва : Лабиринт, 2001. С.3-8.

3. Дементьев В.В. Непрямая коммуникация и ее жанры. Саратов : Изд-во Сарат. ун-та, 2000. 248 с.

4. Дементьев В.В., Седов К.Ф. Теория речевых жанров: социопрагматический аспект. Stylistyka. № 8. 1999. С. 53-87.

5. Зернецкий В.П. Лингвистические аспекты теории речевой деятельности. Киев : Лабиринт, 1988.120 с.

6. Седов К.Ф. Типы языковых личностей и стратегии речевого поведения (о риторике бытового конфликта). Вопросы стилистики. Язык и человек. Вып. 26. Саратов : Изд-во Сарат. ун-та, 1996. С. 8-14.

7. Стернин И.А. Основы речевого воздействия. Воронеж, 2012.178 с.

8. Larson Charles U. Persuasion: reception and responsibility. Belmont : Wadsnorth Publishing Company, 1995. 200 p.

Окулова Л. О. Особливості відтворення стратегії переконання у перекладі українською мовою рекламних текстів американської б'юті-індустрії

Анотація. Статтю присвячено проблемі міждисциплінарного характеру, актуальній одночасно для психо- лінгвістики та перекладознавства. У дослідженні проаналізовано лінгвістичні засоби репрезентації стратегії переконання у рекламних текстах американської б'юті-індустрії та досліджено провідні перекладацькі стратегії, тактики і прийоми їх відтворення засобами української мови. Переконання тлумачиться як розумовий вплив на рішення співрозмовника чи цільової аудиторії щодо спонукання до певних дій чи маніпулювання. Було з'ясовано, що стратегія переконання маніфестується у мовленні за допомогою таких прийомів впливу, як стилістичні засоби, композиційна структура висловлювань, когнітивні та логічні операції. На стилістичному рівні було визначено такі засоби реалізації стратегії переконання, як риторичні питання, паралельні конструкції, лексичні повтори, інверсія, гіпербола, літота та мейозис. Серед прагматичних засобів було виокремлено форми звертань, непрямі мовленнєві акти та мовленнєві акти змішаного типу.

За результатами було доведено пріоритетність стратегій переадресації та терціарного перекладу та поширеність тактик передачі релевантної інформації, коректного оформлення та лінгвокультурної адаптації. Аналіз застосованих перекладацьких прийомів дозволив дійти висновку про кількісне переважання прийомів трансплантації, транскодування, різних видів замін (контекстуальної заміни, конкретизації та функціональної заміни), а на рівні комплексних трансформацій - частотне вживання прийому смислового розвитку та описового й антонімічного перекладу. Дослідження має перспективу, а його результати можуть слугувати засобом оптимізації перекладу у сфері б'юті-індустрії. Також перспектива вбачається у залученні інших індоєвропейських мов, що відкриває нові обрії для типологічного дослідження на матеріалі публікацій у галузі індустрії краси.

Ключові слова: психолінгвістика, стратегія переконання, б'юті-індустрія, перекладацькі стратегії, тактики, прийоми. 